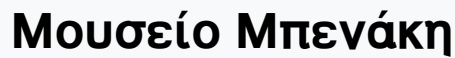

A Singular Antiquity: Archaeology and Hellenic Identity in Twentieth-Century Greece

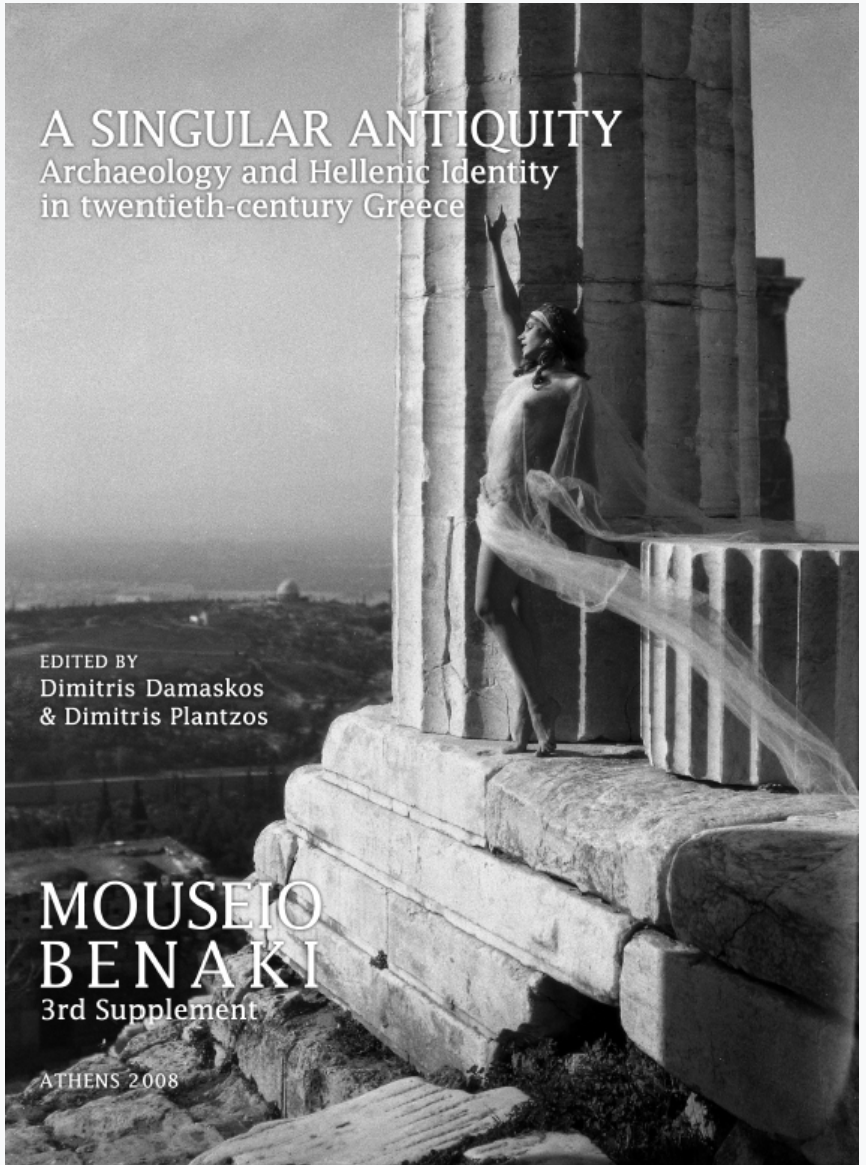

The phantom of classicism in Greek architecture

Dimitris Philippides

doi: $\underline{10.12681 / \text { benaki.18064 }}$

Copyright $@$ 2018, Dimitris Philippides

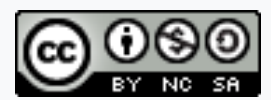

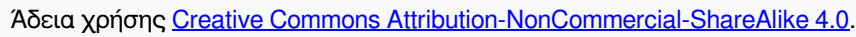

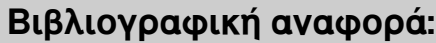

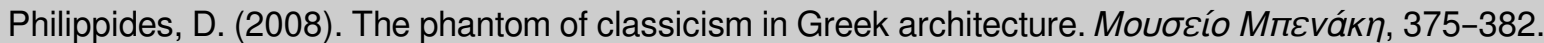

https://doi.org/10.12681/benaki.18064 


\section{The phantom of classicism in Greek architecture}

ON THE THRESHOLD of a new century, one might perhaps surmise that Greece had outgrown the agonizing crisis, which tormented and electrified Greek society during the nineteenth and early twentieth century; that at last, all open accounts with the past and tradition have been closed. Yet, it is highly doubtful that something of the sort will ever happen. Nowadays, the mere emergence of the 'threat' of globalization has sufficed for a resurgence of introspection and nationalistic campaigning. In such periods of turmoil, antiquity is summoned to serve as a foolproof guarantee of stability and ethnic identity; ${ }^{1}$ Alexander the Great will never just be a name in history.

Another national awakening has undermined the positivism of modernization, that is distancing itself from the one-sided notions of progress and Europeanization which dominated Greece in the nineteenth century and more sporadically thereafter. The constant presence of antiquity not only fills the halls - and to an even greater extent the storage rooms - of archaeological museums all over the country and the pages of patriotic history textbooks for schoolchildren, but plays an active part in Greek daily life. ${ }^{2}$

Indicative examples are the major urban renovation project for the centre of Athens which is tellingly entitled the 'Unification of Archaeological Sites'; and, the creation of 'archaeological' excavation wells for the needs of the Athens metro network, with the resulting finds subsequently displayed in situ in the stations as a reminder of 'self-identity'. As a result, a local newspaper could make the justifiable claim that, due to this extensive excavation of Athenian soil, 'In the year 2004, Athens will become [...] ancient. ${ }^{3}$ Antiquity, in those terms, returns in venge- ful mood, claiming full recognition. Archaeologists, on the other hand, those eccentric neo-Romantic servants of the temple, are considered the heroic defenders of national pride and grandeur.

The rekindling of this asphyxiating bond between society and its infatuation with ancient Greece was to affect architecture in various ways, as we shall see. But with a difference: the borrowing of forms and details taken directly from ancient monuments, as was the habit in the nineteenth and the early twentieth centuries would now become optional. And should one desire to do so - a move always favoured by the nouveaux riches and the uncultured - it would be done indirectly and somewhat in jest. Contemporary apologists of a more subtle revival of classicism, such as Demetri Porphyrios, claim that the language of classicism is not a 'style' (fig. 1), that is something susceptible to change over time, but a universal lingua franca, and therefore something eternal. ${ }^{4}$ This notion was widely adapted by the adherents of the new 'humanism', whose reverence for the unexcelled beauty of antiquity, could be seen as a recognizable trend in international architecture. Antiquity lives - regardless of distortions and intermediary filters.

Old wine in new bottles then; but what was the new receptacle? The answer lies in the switch from a positive to a negative sign. If the introduction of Neoclassicism to Greece in 1830 were to be considered a purely modern act, its preservation in the twentieth century could be considered extraordinarily conservative. Still these two opposites share a nostalgia, albeit for different objects. The nineteenth century revived antiquity per se while the 


\section{CLASSICISM}

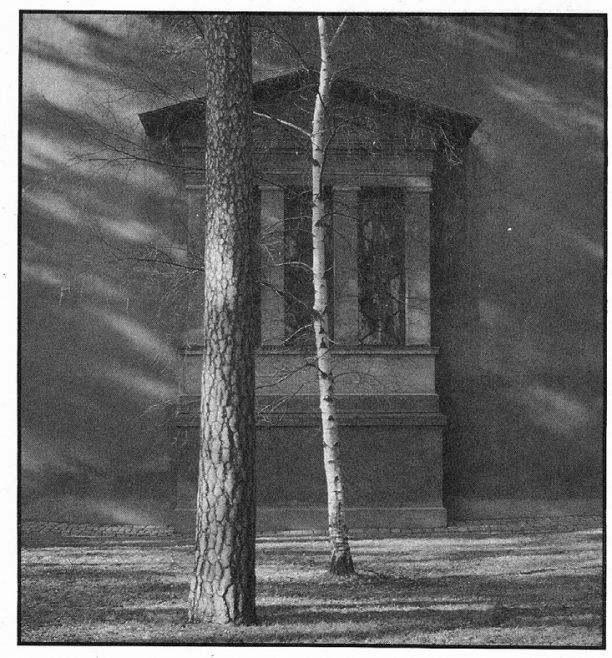

\section{S $\quad \mathrm{N} O \mathrm{O}$ T A $\mathrm{S}$ T Y L E}

Guest-Edited by Demetri Porphyrios

Academy Editions/St Martin's Press

Fig. 1. Front cover of Porphyrios 1982.

late twentieth century revived the new version of antiquity formulated in the previous century. In fact, this shift was already apparent before the close of the nineteenth century, although strong ideological forces suppressed it because it was then impossible to imagine that eternal values, as embedded in antiquity, could evolve into something else. An additional step was taken three decades ago, when this ersatz antiquity, i.e. Neoclassicism, already refined by the passage of time, came under the official protection of the state (1975). This suggests that Greek Neoclassicism, just like Greece itself, will never die - as proclaimed in the lyrics of a well-known Greek military march.

Another change had also occurred; architects no longer climbed up to the Acropolis to study and emulate the art of perfection, but rather as a means to demonstrate their theories. ${ }^{5}$ The Parthenon - as the famous architect Le Corbusier tells us - is a symbol of the robust Doric spirit perfectly adapted to the sincerity of the new revolutionary architecture, that is, modern architecture (1923). ${ }^{6}$ Ironi-
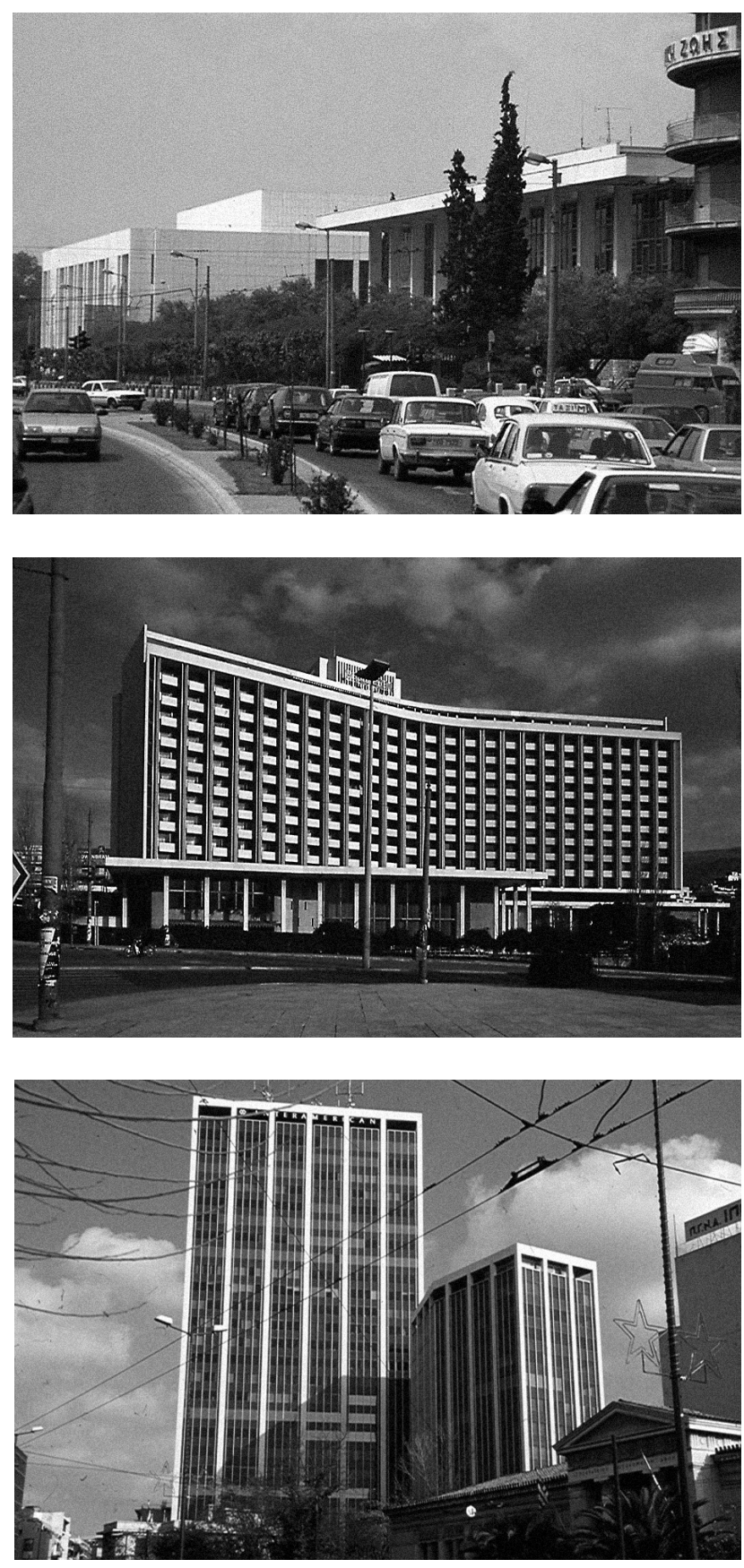

Fig. 2. W. Gropius and TAC, the American Embassy in Athens (1957-61).

Fig. 3. P. Vasileiades, E. Vourekas, S. Staikos, the Athens Hilton hotel (1958-63).

Fig. 4. I. Vikelas, the Athens Tower (1973). 
cally, the same Le Corbusier had previously devised the Domino construction system (1914), which consisted of a concrete frame filled with non load-bearing brick walls, which was widely adopted throughout Greece after the war and could be seen as an extreme case of coarse, debased modernity. ${ }^{7}$

Greek architecture thus entered the twentieth century in full regalia maintaining the impetus originally bestowed upon it by the Greek revival. Neoclassical architecture was still being built in this corner of the globe almost up to the thirties, possibly an unofficial world record. ${ }^{8} \mathrm{~A}$ country like pre-war Greece, plagued by constant, political and social upheavals, was able to preserve a cultural fossil. Thereafter, with all the necessary concessions to the Modern movement, neoclassical architecture has continued to represent the official ideal of the Greek state convincingly up to the present day. These adaptations will be discussed below.

In the post-war period, the shifts would be less perceptible; major emblematic buildings of the early sixties, such as the American Embassy (W. Gropius and TAC, 195761; fig. 2) and the Athens Hilton hotel (P. Vasileiades, E. Vourekas, S. Staikos, 1958-63; fig. 3), impose a shorthand version of the classical: the use of white marble, colonnades, and symmetrical layouts form the language of the new reduction of antiquity to the present. Almost nothing changed thereafter up to the Athens Tower (I. Vikelas, 1973; fig. 4) and the extension to the Ministry of Foreign Affairs (I. Vikelas, 1977; fig. 5). This selective classicizing trend derived mainly from the USA, reflecting America's post-war global cultural supremacy.

In today's multivalent era the lingering charm of classicism is apparent all over the world, directly or indirectly. Since at least the Enlightenment, the appeal of antiquity has always been perceived in international terms. In Greece, however, it was impossible to understand that, while 'antiquity' (meaning exclusively Greek antiquity) and archaeology (again meaning just Greek archaeology) were indigenous gods, classicism - and by extension, Neoclassicism - were international movements. Similarly, the Roman contribution to this tradition receives little attention in Greece even now..$^{10}$

After a while, the identity crisis caused by the 'national trauma' of 1922 posed once again the question as to where Greece stood in relation to its long past, as a defence mechanism against any foreign menace. ${ }^{11}$ But antiquity

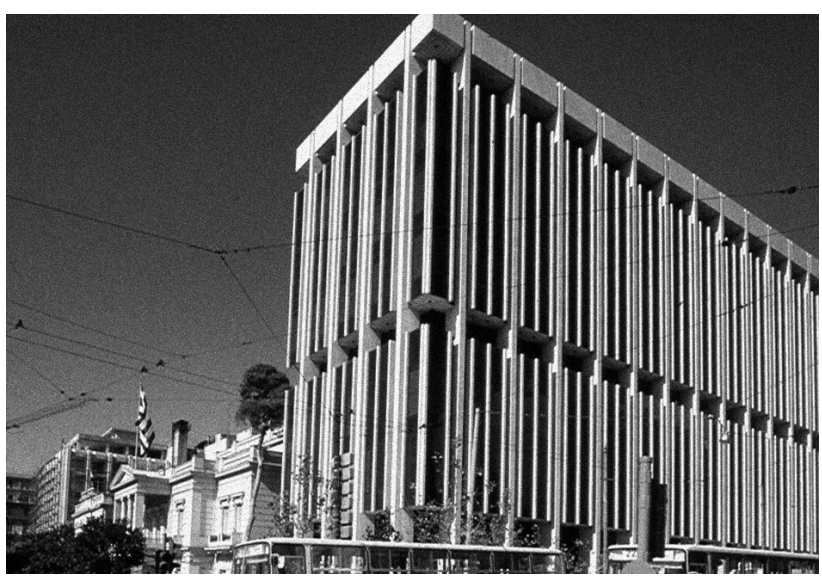

Fig. 5. I. Vikelas, the addition to the Ministry of Foreign Affairs, Athens (1977).

no longer stood alone as a factor in this quest for national self-knowledge; it was joined after 1880 in a haphazard way by all later 'historical phases' of Hellenism. Antiquity had not actually lost its preferential position, but was supplemented by 'transmutations' or 'shifts', which had now lost their routinely added pejorative affixes, e.g. 'barbaric art' or 'a product of the dark ages'. It was thus now time for 'Greekness' to make its appearance; this extremely vague notion of historical syncretism defied all attempts at definition from the thirties onwards. ${ }^{12}$

A prominent interpreter of this extremely complex puzzle was Dimitris Pikionis, primarily an adherent of the notion of cultural continuity as a 'trans-Greek' march in history. He was also the only Greek architect to appropriate a specific ancient Greek house as a model, actually a reconstructed house excavated in Priene (a Hellenistic site in present-day Turkey) to use as a contemporary house in Athens (the Karamanos brothers' house, 1925; fig. 6). To illustrate the marked conflicts of the inter-war period, Pikionis would subsequently experiment with modern architecture only to openly condemn it (1933). ${ }^{13} \mathrm{He}$ immediately turned toward forms derived from tradition - not necessarily Greek tradition. For Pikionis, antiquity was thus one of many alternative sources of beauty; thus, as an 'archaeologist of the past', he created complex memory collages. He also claimed that he was primarily oriented toward the East, meaning that he was an anti-classicist according to the current definition of his times.

Still Pikionis was an exception. Greek society as a whole 


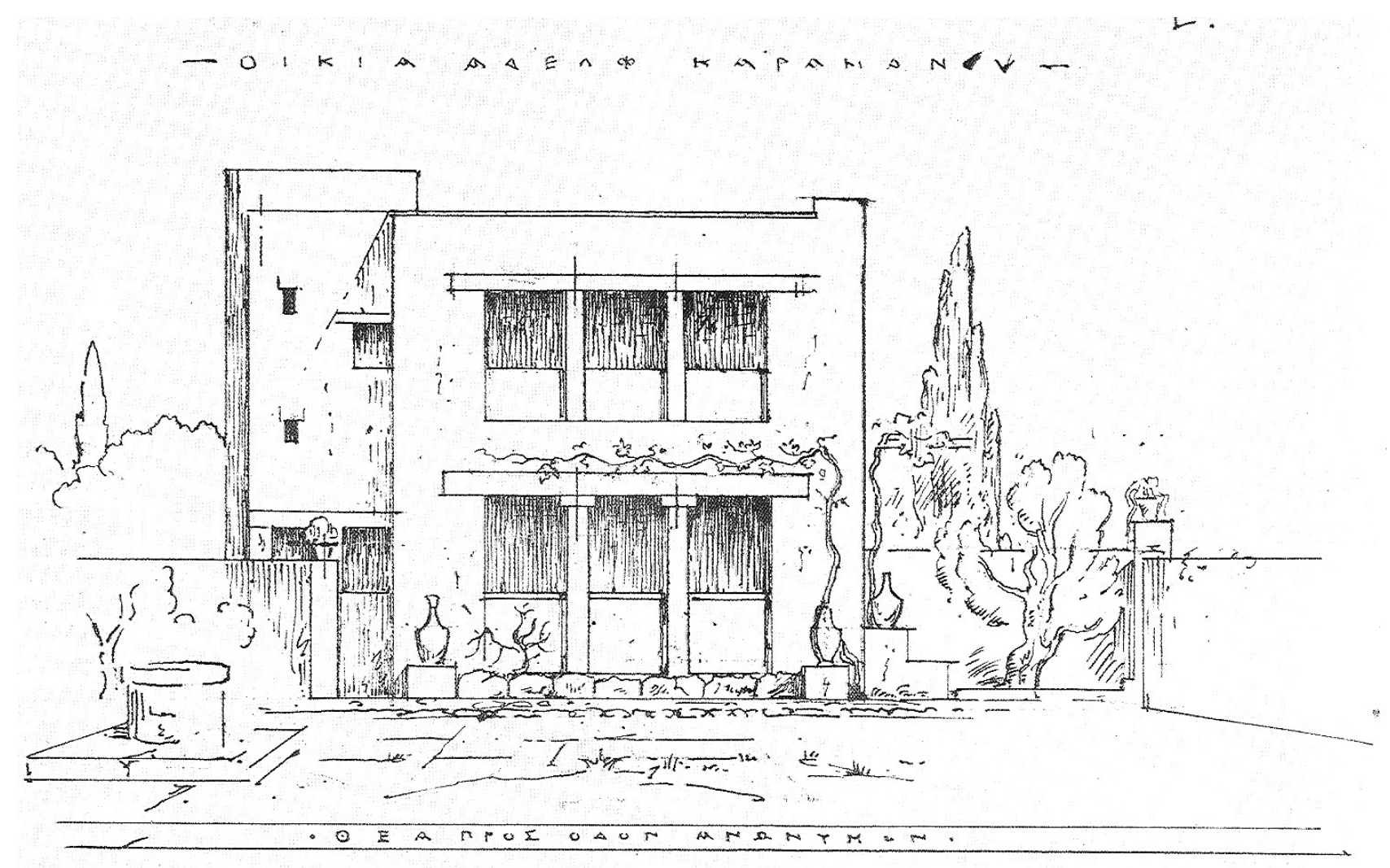

Fig. 6. D. Pikionis, The Karamanos brothers' house, Athens (1925)

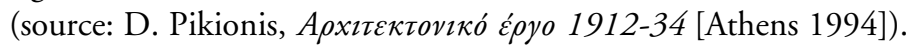

was captivated in the thirties by the new fashion of modernism, which was routinely propounded as a symbol of social and technological progress. Despite this, it lacked the courage to abandon classicism completely. If the avant-garde was attracted by the purity of simple geometrical masses in architecture, the majority of people seemed to prefer a certain 'Greek touch', according to the architect Vassilis Kassandras. ${ }^{14}$ Quite a number of architects in the period 1930-50 were apparently willing to explore this slippery slope. In this they were not alone. Similar, if not identical tendencies can be seen in European architecture before the war, with the use of a 'classicizing modernism', a mix, which added validity to the often rejected modernism. Therefore, this particular trend was not so much meeting a local 'need' as reflecting an imported fashion. Thus, history was repeating a pattern similar to that seen in the introduction of Neoclassicism to Greece after 1830. Yet this initiative gradually lost momentum around the sixties mainly due to the virulent attacks by the prominent architect Aris Konstantinides on any form of historicist 'setting'. He did not hesitate to assail Neoclassicism as a fake, imported architecture. ${ }^{15}$

The short intermission of calm in the inter-war period was superseded by a new cycle of political crisis; not for the first time, antiquity was called upon to serve an important national cause. The dictatorship of 1936-41 propounded the notion of a 'Third Hellenic Civilization', as a euphemism for the present day. It thus flattered naïve nationalism by encouraging the existence of a crude cult of the ancestors. This was readily copied by the dictatorship of 1967-74, avoiding the need to invent another equally striking slogan. In the civil war period between these two dictatorships (1945-49), the ultimate monument for all ages, the Parthenon, was consciously used as a superlative symbol of attainment for the work done in the Makronisos concentration camp. ${ }^{16}$ In the post-1974 period, a typical restitution preserved the same mechanisms but with a certain flair: at least some of the more 

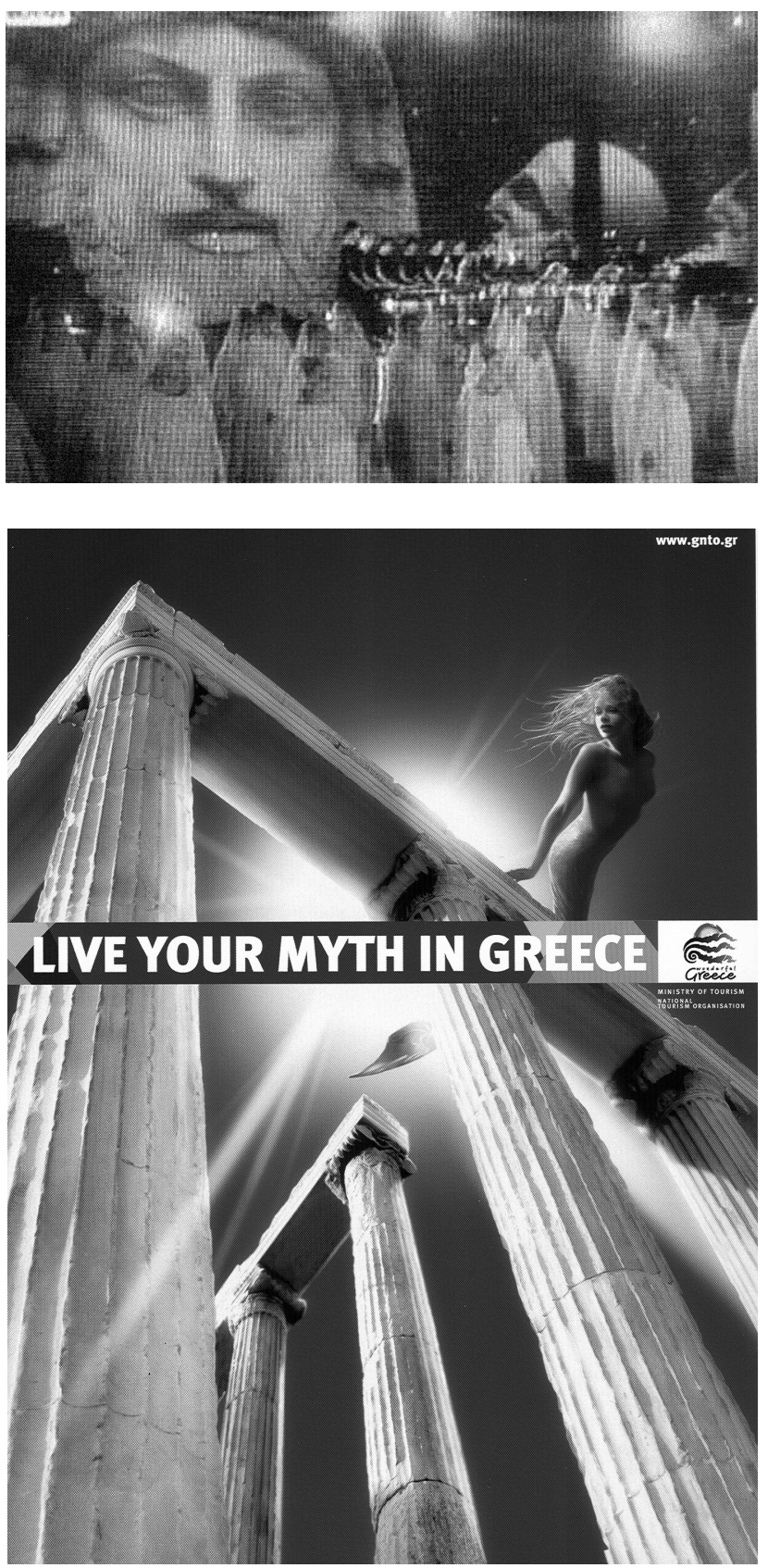

Fig. 7. Vangelis, Mythodia, performance, Cultural Olympiad, Athens (2002) (source: Vouli TV Channel, official video).

Fig. 8. Greek National Tourism Organization poster. recent performances of the Cultural Olympiad (such as Mythodia by the composer Vangelis, 2004; fig. 7), displayed that spirit. Greek antiquity is still a popular commodity that sells well at home; but it sells even better to foreign consumers. A glance at recent promotional ads sponsored by the Greek National Tourism Organization ${ }^{17}$ (fig. 8) shows the continuing pre-eminence of antiquity: 'Come to explore [...] the inspiring culture of the past and the present [...]'. ${ }^{18}$

Once more we return to the magical starting point of the post-war economic miracle in Greece, when the entire country was being rebuilt from scratch. To those emblematic buildings of the early sixties mentioned before the work of a new generation of 'young modern architects' was being added. These architects, such as for example Nikos Valsamakis and Takis Zenetos, owed nothing to the past. Their pure modernism connected Greece once more to the currents of international avant-garde architecture, from which it had been cut off at the outbreak of World War II. The 'heroic' atmosphere of this period was accompanied by extensive demolition of neoclassical buildings with all major cities being reconstructed. Apparently the past, as 'history' or 'archaeology', had receded; the same can be said of the ideological construct of 'Hellenicity', which would be put aside or trashed despite its relentless manipulation. A common notion at the time was that, if something worthwhile was going to happen, it would come from the future rather from the past.

This climate of exuberance, by definition short-lived, was disrupted in 1967, when yet another dictatorship put a stop to any forward motion. This could perhaps be interpreted, in a strictly Greek context, as a post-modern political deviation, which eventually led, toward the end of the seventies, to the emergence of a post-modern 'phase' in architecture - this time, an import. This helped deepen the confusion about the true nature of antiquity. By inserting forms already in use as 'ironic comments' on the history of architecture, Greek architects played with the liberty allowed by such new trends but omitted the element of irony. They thus returned to an antique decorative repertoire consisting of pediments, columns and ornaments in relief - the whole set-up they had previously decided to dispose of. Antiquity once more returned to its birthplace with a vengeance as scenographic inventiveness yet unwilling to pose as indigenous. Such shades of classicism, regardless of how questionable they may seem 

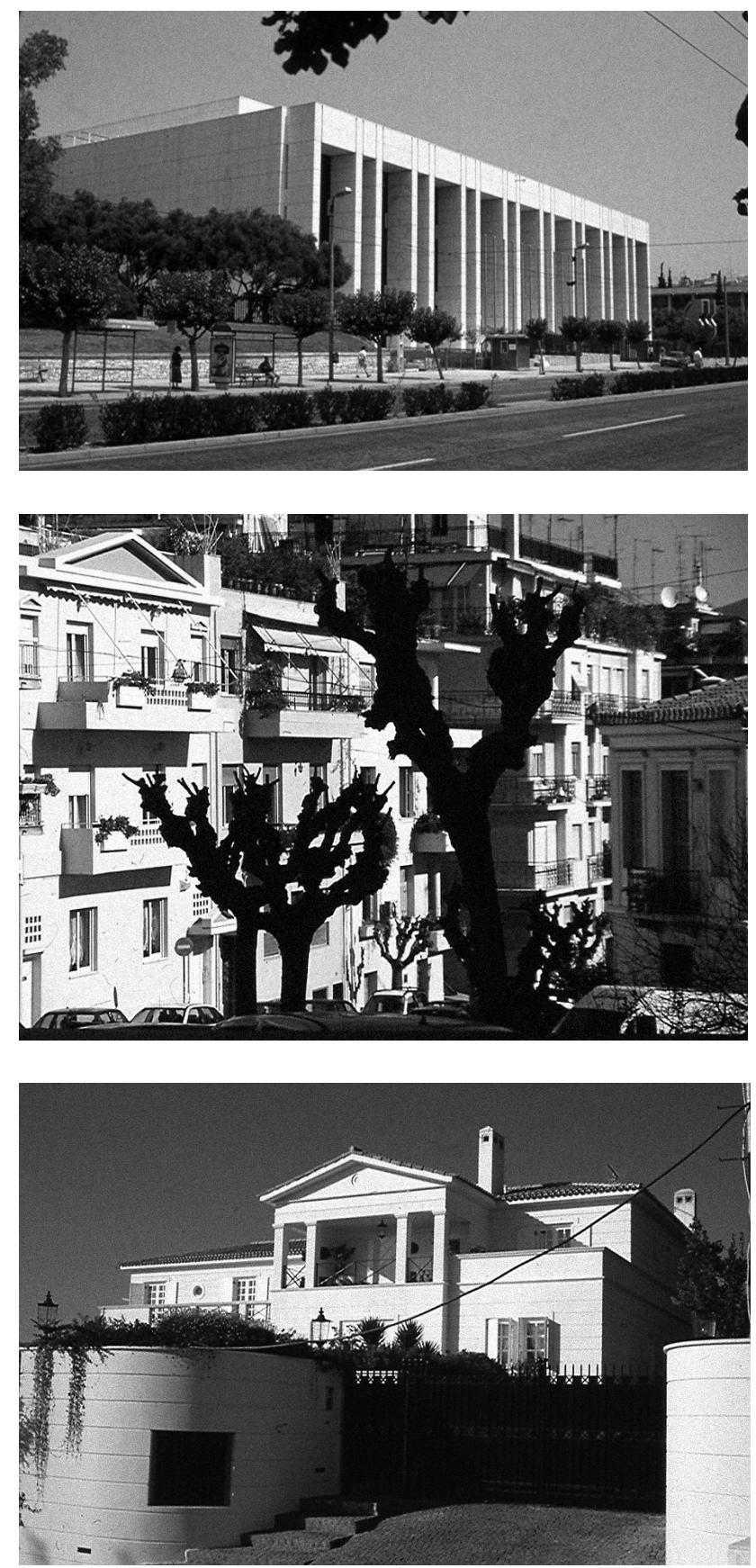

Fig. 9. The Athens 'Megaron' Concert Hall (1976-2001).

Fig. 10. Apartment block in the Koukaki area, Athens.

Fig. 11. Villa in the suburb of Kifissia, Athens.
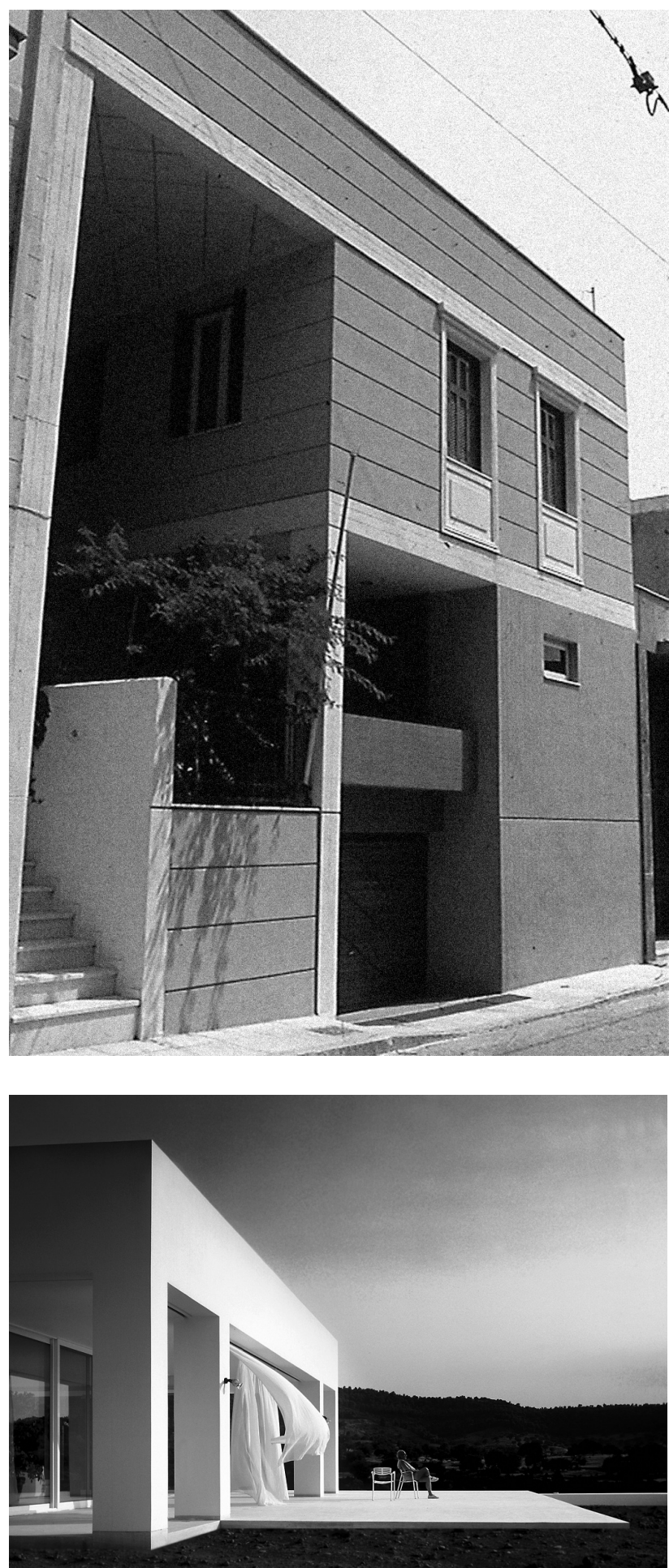

Fig. 12. N. Theodosiou, house at Koukaki, Athens.

Fig. 13. N. Valsamakis, vacation house at Porto-Heli (2002) (photo: D. Kalapodas). 
today, are still in use in Greece combined with a pretentious, blatantly pompous classicism.

Classical style, which, as we noted before, is no longer a 'style', can now be found all over Greece from public buildings (e.g. the Athens 'Megaron' Concert Hall, 19762001; fig. 9), to apartment blocks (fig. 10) and villas in the suburbs (fig. 11). In quantitative terms, this trend is the most popular architecture 'with local colour' built today in a Greek urban context, simply because it is deemed to be purely Greek. A similar situation exists in the countryside, wherever a previous neoclassical tradition existed locally, because nowadays it is listed. In all other parts of the provinces, some of which exhibit much valued traditional form of architecture, state-enforced neo-vernacular architecture is the rule, often embellished with classicizing elements.

It was only natural that such a profusion of decorative forms would provoke a reaction. For example, a small number of architects discovered the charms of vernacular or anonymous architecture as opposed to official or monumental classicism, seen it as a simplified, austere version of the latter (fig. 12). A similar adaptation happened later on when modern architecture was taken up by the lower middle classes. ${ }^{19}$ These variants seemed to radiate the immortal virtues of the place, that is frugality ${ }^{20}$ and purity; thus, they could serve as a handy antidote to the excesses of sensuous post-modernism. This low-key, modest direction was followed by a few architects despite the fact that it ran counter to the contemporary desire for ostentation and

\section{Notes}

* The photos are by the author, unless stated.

1 See, e.g., Huyssen 2001.

2 Cf. Papageorgiou-Venetas 1994, 205-355.

3 Eleftherotypia, 31 January 1999.

4 Porphyrios 1982.

5 Tournikiotis 1994, 200-29.

6 Le Corbusier 1946, 121-38.

7 See also Philippides 1987; Kalogeras 1987.

8 Cf. Biris 1996; Biris 2003; see also Panetsos 2000.

9 See Lowenthal 1988; Lowenthal 1999. even grandiosity, which is fed by rampant consumerism. At least the currently prominent architectural minimalism in Greece, with its extreme economy in the use of materials and of means of expression stemming from modernist abstraction, owes its existence in part to its affinity with classical art, and by extension, to austere classicism.

If the above connection can now be openly discussed, this was not always the case. The continuing tyranny of 'signature' modernism - in fact against all the odds or precisely because of this - impeded our reading of classicism as an underlying framework in the work of prominent contemporary architects in Greece. This definitely holds true in the case of Valsamakis, whose knowledge of the principles of classicism has been translated into thoroughly modern architectural forms, as shown in the holiday home at Porto-Heli (2002; fig. 13). ${ }^{21}$ It seems that we can now begin to discuss, with some certitude, antiquity's influence on the design of modern building projects in Greece. The eternal quest for a return to the glory of the ancestors, through the art of mimesis, suddenly seems a realistic goal. Although rare and far dispersed, the as yet unknown number of specimens of Greek architecture seems to keep the ghost of an utopia alive.

\section{Dimitris Philippides}

Department of Urban and Regional Planning

National and Technical University of Athens

dphil@central.ntua.gr
10 Cf. Hamilakis \& Yalouri 1996.

11 Briefly, this tendency was called 'the Return to the Roots movement' and was represented by such well-known personalities as the folklorist Angeliki Hatzimihalis (1895-1965) and the architect Aristotelis Zahos (1871-1939).

12 See Tziovas 1989.

13 Pikionis 1933.

14 Kassandras 1936.

15 Konstantinides 1950, 13; 21; 29.

16 See Hamilakis 2002; Hamilakis 2007, 205-41.

17 Typical examples are the adventure advertizing campaigns 
entitled 'Live your myth in Greece' (2005) and 'Explore your senses' (2007).

18 Part of the text printed on an 'Explore your senses' ad (2007).

19 These distinctive features, although generally well known, have not yet attracted more detailed study in Greece.

\section{REFERENCES}

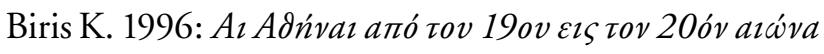
(1st edition 1966; Athens).

Biris M. 2003: Adnvä̈кń a edition 1987; Athens).

Hamilakis Y. 2002: The other Parthenon: antiquity and national memory at Makronisos, Journal of Modern Greek Studies 20, 307-38.

Hamilakis Y. 2007: The Nation and its Ruins: Antiquity, Archaeology and National Imagination in Greece (Oxford).

Hamilakis Y. \& Yalouri E. 1996: Antiquities as symbolic capital in modern Greek society, Antiquity 70, 117-29.

Huyssen A. 2001: Present Pasts: media, politics, amnesia, in: Appadurai A. (ed.), Globalization (Durham and London) 57-77.

Kalogeras N. 1987: The adventures of an ideogram, Architecture in Greece 21, 130-32.

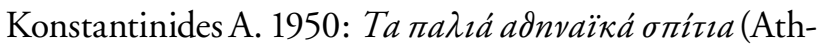
ens).

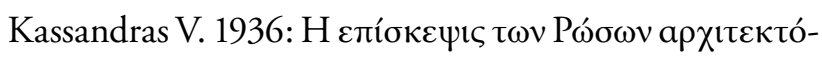

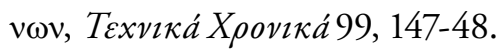

Le Corbusier 1946: Eyes which do not see. III; automobiles, Towards a new architecture (London and New York) 121-38.

Lowenthal D. 1988: Classical antiquities as national and
20 A. Konstantinides distinguishes 'moral frugality' as the main characteristic of 'any truly Greek form' in contrast to Western and Eastern models (Konstantinides 1950, 35).

21 Mies van der Rohe, well known for the classical roots of his works such as the Barcelona Pavilion (1929), acted as an intermediary between the Modern Movement and Valsamakis (Philippides 2007).

global heritage, Antiquity 62, 726-35.

Lowenthal D. 1999: The Past is a Foreign Country (Cambridge).

Panetsos G. 2000: The formation of Athenian Neoclassicism, in: K. Staikos (ed.), Athens from the Classical Period to the Present Day (5th century B.C. - A.D. 2000) (Athens) 398-435.

Papageorgiou-Venetas A. 1994: Athens: the Ancient Heritage and the Historic Cityscape in a Modern Metropolis (Athens).

Porphyrios D. 1982: Classicism is not a Style (London).

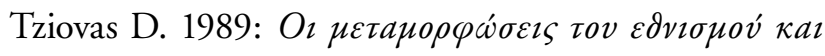

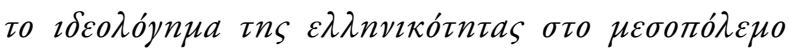
(Athens).

Tournikiotis P. 1994: The place of the Parthenon in the history and theory of modern architecture, in: P. Tournikiotis (ed.), The Parthenon and its Impact in Modern Times (Athens) 200-29.

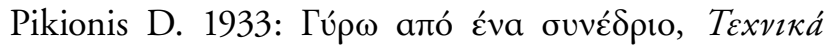
Xооиıкá 39, 755-56.

Philippides D. 1987: Was Le Corbusier guilty or not?, Architecture in Greece 21, 127-29.

Philippides D. 2007: Valsamakis - The passionate quest for architecture, in: Nicos Valsamakis Architect: Exhibition catalogue, Benaki Museum (Athens) 251-63. 